Brit. F. vener. Dis. (1969), 45, 202.

\title{
EFFECT OF 2-MERCAPTOETHANOL TREATMENT ON ANTICARDIOLIPIN REACTIVITY IN SERA FROM SYPHILITICS AND FALSE POSITIVE REACTORS* \\ BY
}

\author{
G. R. TRINGALI $\dagger$, A. J. JULIAN, AND W. M. HALBERT \\ Venereal Disease Research Laboratory, Venereal Disease Branch \\ State and Community Services Division \\ National Communicable Disease Center \\ Health Services and Mental Health Administration \\ Public Health Service \\ U.S. Department of Health, Education, and Welfare \\ Atlanta, Georgia 30333, U.S.A.
}

In a previous paper, Tringali, Del Carpio, and Giammanco (1966) reported that treatment of sera with 2-Mercaptoethanol (2-ME) caused a disappearance of non-syphilitic anticardiolipin reactivity, usually referred to as "false positive" (FP) reactivity, as detected in a complement-fixation assay. However, similar treatment did not abolish the reactivity of syphilitic sera in the same assay. This raised the question of whether or not 2-ME treatment might offer a means of differentiating syphilitic sera from FP reactors.

Since only nine sera were used in the initial study and only complement-fixation reactivity was investigated, it seemed of interest to study the lability of anticardiolipin reactivity to $2-\mathrm{ME}$ in a larger number of sera, and to study the effect of 2-ME on reactivity in a flocculation test (Venereal Disease Research Laboratory [VDRL] slide test), as well as a complement-fixation test (Kolmer one-fifth volume).

\section{Material and Methods}

Sera The Venereal Disease Research Laboratory serum bank supplied 79 FP sera and 118 sera from treated and untreated syphilitic humans in different stages of the disease. Syphilis sera were selected on the bases of history, clinical reports, and reactivity in standard serological tests and the fluorescent treponemal antibody absorption (FTA-ABS) test. The Treponema pallidum immobilization (TPI) test was performed on some of the sera.

False positive sera were selected on the bases of history, clinical reports, non-reactivity in the FTAABS and TPI tests, and persistent reactivity in the VDRL slide flocculation test and Kolmer one-fifth volume complement-fixation tests with cardiolipin antigen.

\footnotetext{
*Received for publication February 18, 1969.

+Present address: Institute of Hygiene, University of Palermo, Sicily, Italy.
}

Treatment of Sera with 2-ME or Phosphate Buffered Saline Sera were treated with 2-ME according to the procedure described by Deutsch and Morton (1957); equal volumes of heated serum $\left(56^{\circ} \mathrm{C}\right.$ for 30 minutes) and 2-ME (0.2 M in phosphate buffered saline [PBS]) were combined and allowed to remain at room temperature for 12 hours. As a control, another aliquot of each serum was combined with an equal volume of PBS. To study the effect of $2-\mathrm{ME}$ treatment on low titre sera, without introducing a $1: 2$ dilution factor, sera from a group of treated syphilitics and from false positive reactors were mixed with a smaller volume of more concentrated $2-\mathrm{ME} ; 0.9 \mathrm{ml}$. serum with $0.1 \mathrm{ml}$. 1.0 M 2-ME. All sera treated with 2-ME or PBS were dialysed against changes of PBS for 36 hours at $4^{\circ} \mathrm{C}$, and were then centrifuged to remove any precipitate. Quantitative VDRL slide tests and Kolmer one-fifth volume tests were performed on all sera before treatment and after treatment with 2-ME or PBS. All specimens were tested on the same day.

\section{Results}

The detailed results are presented in the Table (opposite).

It can be seen that addition of an equal volume, or even of $1 / 10$ volume, of PBS diluted out reactivity in a significant number of sera from treated syphilitics and false positive reactors. On the other hand, reactivity titres in the sera from untreated syphilitics were sufficiently high for the dilution factor itself not to allow reactivity to fall below detectable levels.

In the complement-fixation assay it was found that, compared with saline-treated controls, 2-ME treatment abolished reactivity in 43 (88 per cent.) of 49 sera from false positive reactors, whereas it abolished reactivity in only four (17 per cent.) of 24 sera from treated syphilitics. It did not abolish reactivity in any of $\mathbf{4 8}$ sera from untreated syphilitics.

In the flocculation assay it was found that, compared with saline-treated controls, 2-ME treatment 
TABLB

EFFECT OF 2-MERCAPTOETHANOL ON CARDIOLIPIN TEST REACTIVITY OF SERA FROM SYPHILITICS AND FALSE POSITIVE REACTORS

\begin{tabular}{|c|c|c|c|c|c|c|}
\hline \multirow[b]{2}{*}{ Cardiolipin Test } & \multirow{2}{*}{$\begin{array}{l}\text { Fluid used } \\
\text { to dilute } \\
\text { Reactive } \\
\text { Serum }\end{array}$} & \multirow{2}{*}{$\begin{array}{l}\text { Serum } \\
\text { Diagnostic } \\
\text { Category }\end{array}$} & \multirow{2}{*}{$\begin{array}{l}\text { No. of } \\
\text { Sera } \\
\text { Studied }\end{array}$} & \multicolumn{2}{|c|}{ No. of Sera Reactive } & \multirow{2}{*}{$\begin{array}{l}\text { Per cent. of PBS- } \\
\text { reactive Sera losing } \\
\text { Reactivity after } \\
\text { Treatmerit with } 2-M B\end{array}$} \\
\hline & & & & $\begin{array}{l}\text { After Dilution } \\
\text { with Phosphate- } \\
\text { buffered Saline }\end{array}$ & $\begin{array}{l}\text { After Dilution } \\
\text { with } 2-\mathrm{ME}\end{array}$ & \\
\hline \multirow{4}{*}{$\begin{array}{l}\text { KOLMER } \\
\text { one-fifth Volume } \\
\text { Complement- } \\
\text { Fixacion }\end{array}$} & \multirow[t]{2}{*}{$\begin{array}{l}\text { Equal volume } \\
2-\mathrm{ME} \text { or PBS }\end{array}$} & $\begin{array}{l}\text { Untreated } \\
\text { syphilis }\end{array}$ & 48 & 48 & 48 & 0 \\
\hline & & $\begin{array}{l}\text { False positive } \\
\text { reactor }\end{array}$ & 50 & 30 & 3 & 90 \\
\hline & \multirow[t]{2}{*}{$\begin{array}{l}1 / 10 \text { volume } \\
2-M E \text { or } P B S\end{array}$} & $\begin{array}{l}\text { Treated } \\
\text { syphilis }\end{array}$ & 24 & 24 & 20 & 17 \\
\hline & & $\begin{array}{l}\text { False positive } \\
\text { reactor }\end{array}$ & 22 & 19 & 3 & 84 \\
\hline \multirow{4}{*}{$\begin{array}{l}\text { VDRL } \\
\text { Slide } \\
\text { Flocculation }\end{array}$} & \multirow[t]{2}{*}{$\begin{array}{l}\text { Equal volume } \\
2-M E \text { or } P B S\end{array}$} & $\begin{array}{l}\text { Untreated } \\
\text { syphilis }\end{array}$ & 94 & 94 & 94 & 0 \\
\hline & & $\begin{array}{l}\text { False positive } \\
\text { reactor }\end{array}$ & 57 & 28 & 10 & 64 \\
\hline & \multirow[t]{2}{*}{$\begin{array}{l}1 / 10 \text { volume } \\
2-M E \text { or } P B S\end{array}$} & $\begin{array}{l}\text { Treated } \\
\text { syphilis }\end{array}$ & 24 & 13 & 13 & $\mathbf{0}$ \\
\hline & & $\begin{array}{l}\text { False positive } \\
\text { reactor }\end{array}$ & 22 & 15 & 4 & 73 \\
\hline
\end{tabular}

abolished reactivity in 29 (67 per cent.) of 43 sera from false positive reactors, but it did not abolish reactivity in any of thirteen sera from treated syphilitics or in any of 94 sera from untreated syphilicics.

\section{Discussion}

The present study regarding the 2-ME stability of anticardiolipin reactivity in the sera of syphilitics and false positive reactors confirms in a general way an earlier report by Tringali and others (196\%). However, two additional points have been revealed in this examination of a larger number of sera in two essays. First, there is a relative rather than an absolute difference in the effect of $2-\mathrm{ME}$ on sera from syphilitics and false positive reactors. Although 2-ME usually abolished the reactivity in false positive sera, it did not always do so. From 10 to 27 per cent. of false positive sera retained reactivity after 2-ME treatment. While 2-ME treatment generally did not affect syphilitic sera, in four instances the treatment abolished reactivity.

Secondly, the effect seen after 2-ME treatment is partly dependent on the system used to measure serum reactivity. A greater percentage of false positive sera appeared to lose reactivity in the complement-fixation assay than in the flocculation assay. After 2-ME treatment of syphilitic sera, four lost reactivity in the complement-fixation test but none lost reactivity in the flocculation test.
The FP reactivity that was abolished by $2-\mathrm{ME}$ treatment was probably, but. not necessarily, of the IgM class. It is well established that IgM molecules are split by sulphydryl reagents such as 2-ME, resulting in loss of antibody activity in many assays (Deutsch and Morton, 1957; Bauer and Stavitsky, 1961; Uhr, Finkelstein, and Franklin, 1962). Disruption of IgM has been noted also by immunoelectrophoresis (Kim, Bradley, and Watson, 1964 ; Carpenter and Gill, 1966). On the other hand, we also call attention to reports that antibodies not of the IgM class may be sensitive to $2-\mathrm{ME}$, and that $2-\mathrm{ME}$ may decrease the ability of $7 \mathrm{~S}$ antibody to fix complement (Benedict, Brown, and Hersh, 1963; Wiedermann, Miescher, and Franklin, 1963; Adler, 1965).

The findings in the report indicate that 2-ME treatment might have a place as an adjunct procedure in syphilis serology, but from our data it does not appear that 2-ME treatment by itself can rigorously differentiate false positive reactors from syphilitics. The significance of false positive reactivity which is resistant to $2-\mathrm{ME}$ treatment remains to be determined, but preliminary results from another study (Tringali, in preparation) indicate that it may be a marker of certain underlying systemic diseases.

\section{Summary}

Using complement-fixation (Kolmer one-fifth volume with cardiolipin antigen) and flocculation 
(VDRL slide) tests, the effect of 2-mercaptoethanol treatment on anticardiolipin reactivity was determined, using sera from patients with untreated or treated syphilis and also from patients giving false positive reactions to cardiolipin antigen tests. In the complement-fixation assay it was found that, compared with saline-treated controls, $2-\mathrm{ME}$ treatment abolished reactivity in 43 (88 per cent.) of 49 sera from false positive reactors, in contrast with only 4 (17 per cent.) of 24 sera from treated syphilitics. In no case did it abolish reactivity in 48 sera from untreated syphilitics. In the flocculation assay it was found that, compared with saline-treated controls, 2-ME treatment abolished reactivity in 29 (67 per cent.) of 43 sera from false positive reactors, but in none of thirteen sera from treated syphilitics or of 94 sera from untreated syphilitics.

We thank Dr. G. R. Cannefax for helpful advice and comments, and Dr. L. C. Norins for perusal of the manuscript.

\section{REFERENCES}

ADLER, F. L. (1965). F. Immunol., 95, 26.

Bauer, D. C., and Stavitsky, A. B. (1961). Proc. nat. Acad. Sci. (Wash.), 47, 1667.

Benedict, A. A., Brown, R. J., and Hersh, R. (1963). Proc. Soc. exp. Biol. (N.Y.), 113, 136.

CARPENTER, C. B., and Gill, T. J. (1966). Immunology, $10,355$.

Deutsch, H. F., and Morton, J. I. (1957). Science, 125, 600.

Kim, Y. B., Bradley, S. G., and Watson, D. W. (1964). f. Immunol., 93, 798.
TrINGali, G. (in preparation). Inhibition of sero-reactivity of human syphilitic and BFP sera by 2mercaptoethanol.

-, Del Carpio, C., and Giammanco, N. (1966). Riv. Ist. sieroter. ital., 41, 291.

Uhr, J. W., Finkelstein, M. S., and Franklin, E. C. (1962). Proc. Soc. Exp. Biol. (N.Y.), 111, 13.

WIEDERMANN, G., Miescher, P. A., and FrankLin, E. C. (1963). Ibid., 113, 609.

Effet du traitement au 2-Mercaptoethanol sur la réactivité anticardiolipidique de sérums de syphilitiques et de réacteurs faussement positifs

\section{RÉsumé}

Les épreuves de fixation du complément (Kolmer au $1 / 5$ avec antigène cardiolipidique) et de flocculation (VDRL sur lame) ont été utilisées pour déterminer l'effet du traitement au 2-Mercaptoethanol sur la réactivité anticardiolipidique de sérums de syphilitiques traités ou non traités et aussi de sujets présentant des réactions faussement positives aux épreuves à l'antigène cardiolipidique. Pour la réaction de fixation du complément, il a été constaté que le traitement au 2-ME, comparé au traitement de contrôle au sérum salé, supprimait la réactivité pour 43 (88 pour cent) parmi 49 sérums faussement positifs et pour 4 (17 pour cent), par contre, parmi 24 sérums de syphilitiques traités. Dans aucun cas, la réactivité ne fut supprimée pour les sérums de 48 syphilitiques traités.-Pour la réaction de flocculation, et par comparaison au traitement de contrôle au sérum salé, le traitement au 2-ME supprimait la réactivité pour 29 (67 pour cent) parmi 43 sérums faussement positifs, mais sans modifier la réponse pour 13 sérums de syphilitiques traités et pour 94 sérums de syphilitiques non traités. 